\title{
Synthesis of Aberrant Decay-accelerating Factor Proteins by Affected Paroxysmal Nocturnal Hemoglobinuria Leukocytes
}

\author{
Donna J. Carothers, * Sandra V. Hazra, ${ }^{\ddagger}$ Steven W. Andreson, $\$$ and M. Edward Medof* \\ *Institute of Pathology, Case Western Reserve University, and ${ }^{\S}$ The Cleveland Clinic, Cleveland, Ohio 44106; \\ and ${ }^{\ddagger}$ Akron General Medical Center, Akron, Ohio 44307
}

\begin{abstract}
Paroxysmal nocturnal hemoglobinuria (PNH) leukocytes fail to express decay-accelerating factor (DAF) but contain DAF mRNA transcripts resembling those in normal cells. To further investigate the nature of the DAF defect in affected cells, patients' polymorphonuclear and mononuclear leukocytes (PMN and MNC) were biosynthetically labeled and newly synthesized DAF proteins examined. Analyses of $>98 \%$ surface DAF-negative PMN and MNC from a patient with PNH III erythrocytes showed precursor DAF protein $\sim 3 \mathrm{kD}$ smaller in each cell type than in normal cells. The proportion of precursor to mature ( $O$-glycosylated) DAF protein was increased and soluble DAF protein was detected in the medium. Studies of $70-80 \%$ surface DAF-negative PMN and MNC from four patients with type II erythrocytes showed mixtures of the $3 \mathrm{kD}$ smaller and normal DAF precursors. Partitioning with Triton X-114 detergent and biosynthetic labeling with the anchor precursor $\left[{ }^{3} \mathbf{H}\right]$ ethanolamine indicated that the abnormal peptides lacked glycosyl-inositolphospholipid membrane-anchoring structures. Thus, in PNH cells nascent DAF polypeptides are synthesized. Some of the abnormal pro-DAF molecules are processed in the Golgi and some are released extracellularly. (J. Clin. Invest. 1990. 85:47-54.) decay-accelerating factor • glycosyl-inositolphospholipid anchor • paroxysmal nocturnal hemoglobinuria
\end{abstract}

\section{Introduction}

Paroxysmal nocturnal hemoglobinuria (PNH) ${ }^{1}$ is an acquired disorder in which subpopulations of blood elements that are unable to regulate autologous complement appear in the cir-

The data in this paper were presented in part at the annual meeting of the Federation of the American Society for Experimental Biology, 6 May 1988 (Carothers, D. J., H. A. Stafford, S. V. Hazra, and M. E. Medof. 1988. Identification of aberrant DAF proteins in affected PNH leukocytes. FASEB [Fed. Am. Soc. Exp. Biol.] J. 2:1643a. [Abstr.]).

Address correspondence to Dr. M. Edward Medof, Institute of Pathology, Case Western Reserve University, 2085 Adelbert Road, Cleveland, OH 44106.

Received for publication 23 November 1988 and in revised form 24 August 1989.

1. Abbreviations used in this paper: $\mathrm{DAF}$, decay-accelerating factor, $\mathrm{E}$, erythrocytes; GPL, glycosyl-inositolphospholipid; HRF, homologous restriction factor, IRMA, immunoradiometric assay; MNC, mononuclear leukocytes; PI-PLC, phosphatidylinositol-phospholipase C; PNH, paroxysmal nocturnal hemoglobinuria.

J. Clin. Invest.

(c) The American Society for Clinical Investigation, Inc.

0021-9738/90/01/0047/08 \$2.00

Volume 85, January 1990, 47-54 culation. Activation of the cascade on the surface of these cells results in intravascular hemolysis, thromboembolic events, and leukocyte abnormalities (reviewed in reference 1). The disease is believed to result from the clonal expansion of blood cell progenitors altered by somatic mutation. The nature and site of the genetic alteration(s) are unknown.

A hallmark of affected PNH cells is accumulation of autologous C3 activation fragments on their membranes (2). This abnormality is causally related to deficiency of the decay-accelerating factor (DAF; 2-4), a membrane-associated complement regulatory protein that interferes with formation of autologous $\mathrm{C} 3$ convertases and thereby protects blood cells from complement activation on their surfaces $(4,5)$. Despite the importance of the DAF defect in PNH pathogenesis, however, it only partially accounts for the phenotype of the disorder since affected cells lack other membrane molecules (1). Erythrocytes $(E)$ show deficits of acetylcholinesterase $(6,7)$ and lymphocyte function associated antigen-3 $(8,9)$, PMN exhibit deficiencies of alkaline phosphatase (10) and $\mathrm{Fc} \gamma$ receptor type III (CD16) (11), and mononuclear cells (MNC) show diminished $5^{\prime}$ nucleotidase (12). Correlative analyses of these different defects in PNH cells $(13,14)$ have shown that they overlap in the same cell populations.

Two patterns of cell abnormalities are recognized in PNH. In some patients, affected E (designated type II) exhibit fivefold greater sensitivity to complement-mediated lysis than normal E, while in others affected E (designated type III) exhibit 15-25-fold increased sensitivity (1). Patients with either type of $E$ show variable proportions of complement-resistant, presumably unaffected $\mathrm{E}$ (designated type I), since unaltered as well as altered progenitors are present in their marrow. In the former individuals, DAF-negative and -positive subpopulations of PMN, monocytes, and platelets are similarly distinguishable, whereas in the latter, only DAF-negative PMN, monocytes, and platelets are found $(13,15)$. Recent studies $(16,17)$ have shown that the augmented complement sensitivity of type III $\mathrm{E}$ is secondary to the absence of a membrane inhibitor of autologous $\mathrm{C} 9$ uptake/polymerization, termed homologous restriction factor (HRF), as well as DAF. However, the mechanisms accounting for the differential expression of HRF in type II and III PNH E and for the difference in affected leukocyte distributions associated with the two E types are unknown.

Biochemical $(18,19)$ and enzymatic $(9,20,21)$ studies have provided evidence that each of the deficient molecules in PNH cells (including HRF [22-24]) is membrane-anchored via a glycosyl-inositolphospholipid (GPL) moiety rather than by a conventional membrane-spanning polypeptide domain. Biosynthetic labeling of proteins anchored in this way has shown that the GPL-anchoring structures are preassembled in cells and are incorporated en bloc into nascent polypeptides immediately posttranslationally in the rough endoplasmic reticulum (reviewed in references 25 and 26). Sequence analyses 
of cDNAs have indicated that these proteins are initially synthesized with $\mathrm{COOH}$-terminal extensions resembling polypeptide anchors, but that these extensions are removed from nascent polypeptides concurrent with GPL-anchor attachment. These observations have prompted the suggestion that a defect in the assembly or protein attachment of the GPL structure could underlie PNH.

The recent isolation of DAF cDNAs $(27,28)$ established that DAF conforms to the above pattern and permitted comparative analyses of the DAF genome and DAF mRNA transcripts in PNH and normal cells (29). Southern analyses of affected leukocytes showed DNA restriction fragment profiles identical to those of normal leukocytes. Similarly, Northern analyses revealed DAF mRNA species qualitatively and quantitatively indistinguishable from normal DAF transcripts. These findings suggested that DAF gene structure and function in PNH cells is intact. Whether the DAF mRNA can be translated, however, remained unestablished.

In the present study, biosynthetic labeling analyses of circulating peripheral blood leukocytes (30-32) of PNH patients were carried out and DAF polypeptides newly synthesized by affected cells were examined by SDS-PAGE/fluorography and TX-114 detergent partitioning of cell extracts and by immunoradiometric assay (IRMA) of culture media. The analyses revealed DAF precursors in affected cells $\sim 3,000$ smaller in apparent $M_{\mathrm{r}}$ than those in normal cells, and increased concentrations of soluble DAF polypeptides in affected cell supernates as compared with control media. These findings constitute the first demonstration of defective protein synthesis by affected PNH cells.

\section{Methods}

Proteins and reagents. Anti-DAF MAbs (IA10, IIH6, and VIIIA7) were prepared as described (15). Anti-RPC5 and -MOPC nonrelevant MAbs were from Cappel Laboratories (Cochranville, PA). L- $\left[{ }^{35} \mathrm{~S}\right] \mathrm{Cys}$ (370 $\mathrm{mBq} / \mathrm{ml}), \mathrm{L}-\left[3-{ }^{3} \mathrm{H}\right] \mathrm{Thr}(37 \mathrm{mBq} / \mathrm{ml}), \mathrm{L}-\left[3-{ }^{3} \mathrm{H}\right] \mathrm{Ser}(37 \mathrm{mBq} / \mathrm{ml})$, and $\left[1-{ }^{3} \mathrm{H}\right]$ ethan-1-ol-2-amine hydrochloride $(37 \mathrm{mBq} / \mathrm{ml})$ were purchased from Amersham Corp. (Arlington Heights, IL). Protein A-Sepharose was purchased from Zymed (San Francisco, CA).

Dialyzed fetal bovine serum and RPMI-1640 Select-amine kit were obtained from Gibco Laboratories (Grand Island, NY). Ficoll and dextran T-500 were from Pharmacia Fine Chemicals (Piscataway, NJ), Hypaque-M (75\%) was from Winthrop-Breon Laboratories (New York, NY), and heparin (1,000 U. S. Pharmacopeia units $/ \mathrm{ml}$ ) was from Elkins-Sinn (Cherry Hill, NJ). Triton X-114 detergent and aprotinin were from Sigma Chemical Co. (St. Louis, MO).

Clinical specimens. PNH patients were followed at Case Western Reserve University (M.W.), Cleveland Clinic (D.O. and C.P.), and Akron General Hospital (J.V. and J.B.). All had consistent clinical manifestations and laboratory findings (including positive Ham tests). Bystander lysis (in cobra venom-treated serum [13]) and complement lysis sensitivity assays (the latter performed courtesy of W. Rosse, Duke University Medical Center) showed that J.V. had exclusively affected type III $E$ and that all other patients had variable proportions of type II E. Healthy laboratory and clerical volunteers served as controls. Blood specimens were collected in heparin $(10 \mathrm{U} / \mathrm{ml})$ and patients' and controls' samples were processed in parallel.

Cell fractionations. Heparinized blood was mixed (1:1) with PBS containing $5 \mathrm{mM}$ EDTA, underlayered with Ficoll-Hypaque ( $d$ $=1.358$ ), and centrifuged for $30 \mathrm{~min}$ at $400 \mathrm{~g}$ at $20^{\circ} \mathrm{C}$. MNC harvested from the interface were washed with PBS-EDTA. PMN contained in the pellets were mixed with PBS-EDTA and $4.5 \%$ dextran (in PBSEDTA; $1: 1: 1$ ) and allowed to settle for $30 \mathrm{~min}$ at $20^{\circ} \mathrm{C}$. After removal of contaminating $\mathrm{E}$ by lysis for $1 \mathrm{~min}$ with 3 vol of water, $3.6 \% \mathrm{NaCl}$ was added and the PMN were washed with PBS-EDTA. Monocytes were separated from lymphocytes by incubating $5 \times 10^{6} \mathrm{MNC} / \mathrm{ml}$ for 60 min at $37^{\circ} \mathrm{C}$ in $5 \% \mathrm{CO}_{2}$ on 100 -mm tissue culture dishes (BectonDickinson and Co., Lincoln Park, NJ) and collecting adherent cells, and DAF-negative PMN subpopulations were purified by incubating 1 $\times 10^{6} \mathrm{cells} / \mathrm{ml}$ for $30 \mathrm{~min}$ at $20^{\circ} \mathrm{C}$ on dishes precoated with anti-DAF MAb IA10 $(20 \mu \mathrm{g} / \mathrm{ml})$ and decanting nonadherent cells.

Biosynthetic labeling. PMN or MNC were suspended to 2-5 $\times 10^{6}$ cells/ml in Cys- or Cys-, Ser-, and Thr-deficient RPMI-1640 supplemented with glutamine and $20 \%$ dialyzed heat-inactivated $\left(56^{\circ} \mathrm{C}\right.$ for $30 \mathrm{~min}$ ) fetal bovine serum. After preincubation for $1 \mathrm{~h}$ at $37^{\circ} \mathrm{C}, 500$ $\mu \mathrm{Ci}\left[{ }^{35} \mathrm{~S}\right] \mathrm{Cys}$ or $500 \mu \mathrm{Ci}\left[{ }^{35} \mathrm{~S}\right] \mathrm{Cys}$ and $100 \mu \mathrm{Ci}\left[3-{ }^{3} \mathrm{H}\right] \mathrm{Thr}$ and $100 \mu \mathrm{Ci}$ [3- $\left.{ }^{3} \mathrm{H}\right] \mathrm{Ser}$, respectively, were added and incubation was continued at $37^{\circ} \mathrm{C}$ for $4 \mathrm{~h}$. For ethanolamine labeling, cells were preincubated in RPMI supplemented with glutamine and $20 \%$ dialyzed heat-inactivated fetal bovine serum. $2 \mathrm{mCi}$ of $\left[{ }^{3} \mathrm{H}\right]$ ethanolamine were added and incubation continued at $37^{\circ} \mathrm{C}$ for $4 \mathrm{~h}$. Labeled cells were separated by centrifugation and media saved for analysis (see below). Washed cell pellets were extracted with $500 \mu$ l of boiling $20 \mathrm{mM}$ Tris-HCl, pH 7.4, containing $2 \%$ SDS and $100 \mathrm{U} / \mathrm{ml}$ aprotinin and extracts transferred to Eppendorf tubes. After sonication for $15 \mathrm{~s}$, boiling for $3 \mathrm{~min}$, and centrifugation to remove insoluble materials, extracts were diluted 1:5 with $50 \mathrm{mM}$ Tris-HCl, pH 7.4, containing $190 \mathrm{mM} \mathrm{NaCl}, 6 \mathrm{mM}$ EDTA, $2.5 \%$ Triton $\mathrm{X}-100,0.02 \% \mathrm{NaN}_{3}$, and $100 \mathrm{U} / \mathrm{ml}$ aprotinin (solution A).

Immunoprecipitations and SDS-PAGE/fluorography. Samples of cell extracts were preadsorbed for $2 \mathrm{~h}$ at $20^{\circ} \mathrm{C}$ with $100 \mu \mathrm{l}$ of $10 \%$ protein A-Sepharose in solution A containing $1 \mathrm{mg} / \mathrm{ml}$ ovalbumin. After centrifugation, supernatants were transferred to new tubes, pooled anti-DAF (IA 10, IIH6, and VIIIA7, $5 \mu \mathrm{g} / \mathrm{ml} \mathrm{each;} \mathrm{see} \mathrm{reference}$ 15) or nonrelevant (anti-RPC5 and -MOPC, 5 and $10 \mu \mathrm{g} / \mathrm{ml}$, respectively) MAbs added, and the mixtures rotated for $2 \mathrm{~h}$ at $20^{\circ} \mathrm{C}$. Immune complexes were precipitated by addition of $100 \mu$ l protein A-Sepharose (10\% in solution A with $1 \mathrm{mg} / \mathrm{ml}$ ovalbumin) and rotation for $1 \mathrm{~h}$ at $20^{\circ} \mathrm{C}$. Centrifuged beads were thoroughly washed and immunoprecipitated proteins were extracted by addition of $50 \mu \mathrm{l}$ SDS-PAGE sample buffer (10\% SDS, 10\% glycerol, 2 mM EDTA, $50 \mathrm{mM}$ Tris$\mathrm{HCl}$, pH 7.5, 0.02\% Bromphenol blue) and boiling for $3 \mathrm{~min}$.

SDS-PAGE was performed on nonreduced $7.5 \%$ slab gels by the method of Laemmli (33). Gels were treated with EN $^{3}$ HANCE (New England Nuclear, Boston, MA) or 2,5-diphenyloxazole (Sigma Chemical Co.) in DMSO before drying and autoradiographs prepared at $-70^{\circ} \mathrm{C}$ on X-OMAT XAR-5 film (Eastman Kodak Co., Rochester, NY).

IRMA for $D A F$. Cell extracts and supernatants were prepared and the two-site assay (using anti-DAF MAb IA10 as capturing and IIH6 as detection reagents) carried out exactly as described in reference 15.

Flow cytometry. Leukocytes were stained with anti-DAF (IA 10) or nonrelevant MOPC (Litton Bionetics, Inc., Kensington, MD) MAb of corresponding subclass followed by heavy and light chain-specific, FITC-conjugated sheep $\mathrm{F}\left(\mathrm{ab}^{\prime}\right)_{2}$ anti-mouse IgG (Cappel Laboratories) and analyzed on a cytofluorograph 2S (Ortho Diagnostic Systems Inc., Westwood, MA) as described $(15,29)$.

\section{Results}

Characterization of patients' blood cells. Fig. 1 shows flow cytometric analyses of anti-DAF MAb-stained blood cells from the five PNH patients studied compared with those of blood cells from a normal control. Patient J.V. (with exclusively type III-affected E [see Methods]) exhibited virtually 100\% DAF-negative PMN, while patients J.B., M.W., D.O., and C.P. (with type II E) showed discrete subpopulations of DAF-positive $(20,30,25$, and $30 \%$, respectively) and -negative PMN. Similarly, patient J.V. demonstrated essentially DAF- 


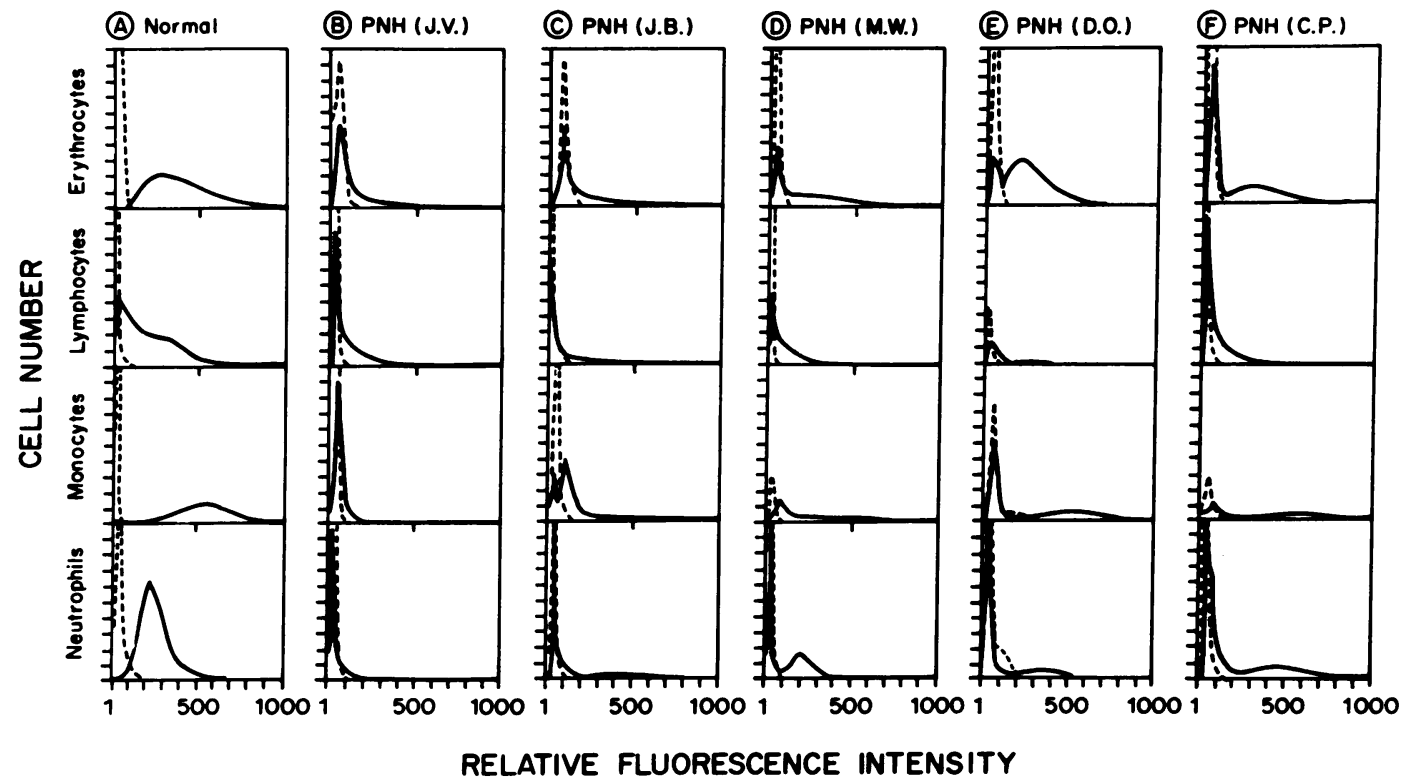

Figure 1. Flow-cytometric analyses of $E$ and leukocytes from a representative normal individual $(A)$ and five PNH patients $(B-F)$. E were stained with a mixture of three MAbs (IA10, IIH6, and VIIIA7) to DAF and FITC-sheep $F\left(a b^{\prime}\right)_{2}$ antimouse IgG (solid lines). Dashed lines represent the same cells stained with a mixture of MAbs of corresponding subclasses, but directed against nonrelevant antigens. Buffy coat cells were stained with antiDAF MAb IA 10 or a single corresponding nonrelevant MAb. negative monocytes and predominantly DAF-negative lymphocytes, while patients J.B., M.W., D.O., and C.P. exhibited discrete DAF-negative and -positive monocyte subpopulations resembling their PMN subpopulations. The latter four patients showed lymphocytes with wide distributions of DAF levels corresponding to those of patients with type II $\mathrm{E}$ that have been described previously (15).

Identification of aberrant DAF polypeptides in patients' leukocytes. PMN and MNC from the five PNH study patients and from five healthy control subjects were labeled with $\left[{ }^{35} \mathrm{~S}\right]-$ Cys, and anti-DAF immunoprecipitates of cell extracts prepared as described in Methods. SDS-PAGE/fluorographs of the immunoprecipitated proteins are shown for studies of J.V. (the single patient with $100 \%$ DAF-negative leukocytes) in Fig. 2, and for studies of J.B. and M.W. (representative patients with mixed populations of DAF-negative and -positive leukocytes) in Fig. 3.

In PMN of patient J.V. (Fig. $2 A$ ) small amounts of mature DAF protein were apparent. This contrasts with findings in PMN of patient J.B. (Fig. $3 A$ ), as well as M.W., D.O., and C.P. (not shown), with mixed populations of cells, in which larger amounts of mature DAF protein (deriving from unaffected as well as affected cells) were seen. In all cases, more abundant amounts of intracellular DAF precursor (in patients with type II E deriving from unaffected as well as affected cells) were present than in the control cells. With patient J.V. (exhibiting precursor deriving exclusively from affected cells) and normal control J.W. (Fig. $2 A$ ) densimetric measurements showed $79 \%$, as compared with $6 \%$ of the total DAF protein in the precursor band. In many studies, lower molecular weight species (presumably representing degradation products) were present in variable amounts, but no differences were detectable in any experiments between patient and control pairs.

In all patients the precursor and mature DAF molecules that were present migrated with lower apparent $M_{\mathrm{r}}$ than corresponding species in normal PMN. In patients with peptides deriving from mixed populations of cells (e.g., D.O.), separation of DAF-negative PMN (by elution of nonadherent cells from anti-DAF MAb-coated plates) and biosynthetic labeling of the purified cells verified that the DAF-negative PMN population was the source of the more rapidly migrating DAF peptides (not shown). Side-by-side analyses on long-run SDSPAGE/fluorographs demonstrated that the abnormal DAF proteins in different patients (J.V., J.B., M.W., and C.P.) migrated with the same mobility. Taking normal precursor and mature PMN DAF proteins as 47 and $80 \mathrm{kD}$, respectively, comparative sizing of J.V.'s peptides (Fig. $2 \mathrm{~B}$ ) yielded apparent $M_{r} s$ of 44,000 and 77,000, the mobility of the latter protein corresponding to that of phosphatidylinositol-specific phospholipase C (PI-PLC) cleaved normal surface PMN DAF. The detection of aberrant $O$-glycosylated mature DAF protein in patient J.V. with virtually $100 \%$ affected cells indicates that some of the abnormal DAF precursor proteins synthesized in PNH cells can undergo Golgi processing (19).

In MNC of patient J.V. (Fig. $2 A$ ) with essentially DAFnegative monocytes and predominately DAF-negative lymphocytes (see Fig. 1), as observed with PMN, reduced amounts of mature DAF, greater abundance of precursor DAF, and reductions in the apparent $M_{\mathrm{r}} \mathrm{s}$ of both were evident. In patient M.W. (Fig. 3 B) and J.B., C.P., and D.O. (not shown) with unaffected as well as affected monocytes and lymphocytes (see Fig. 1), bands corresponding to precursor and mature DAF protein were broader and more diffuse, suggesting the presence of a mixture of abnormal and normal DAF proteins. Comparable banding patterns were observed in studies of purified monocytes of patients C.P. and J.B. (not shown).

Detection of soluble DAF proteins in PNH culture supernatants. To investigate the fate of the aberrant DAF proteins synthesized in PNH cells, culture media of PNH and control cells were assayed for DAF antigen by two-site IRMA based on anti-DAF MAbs (15). The results summarized in Table I showed that culture media from PNH PMN and MNC contained DAF levels higher than supernatants from control PMN and MNC. Plasmas separated from the patients' blood samples exhibited corresponding increases in DAF antigen levels.

Characterization of the abnormal PNH DAF molecules. To determine if the aberrant DAF proteins detected in the PNH 

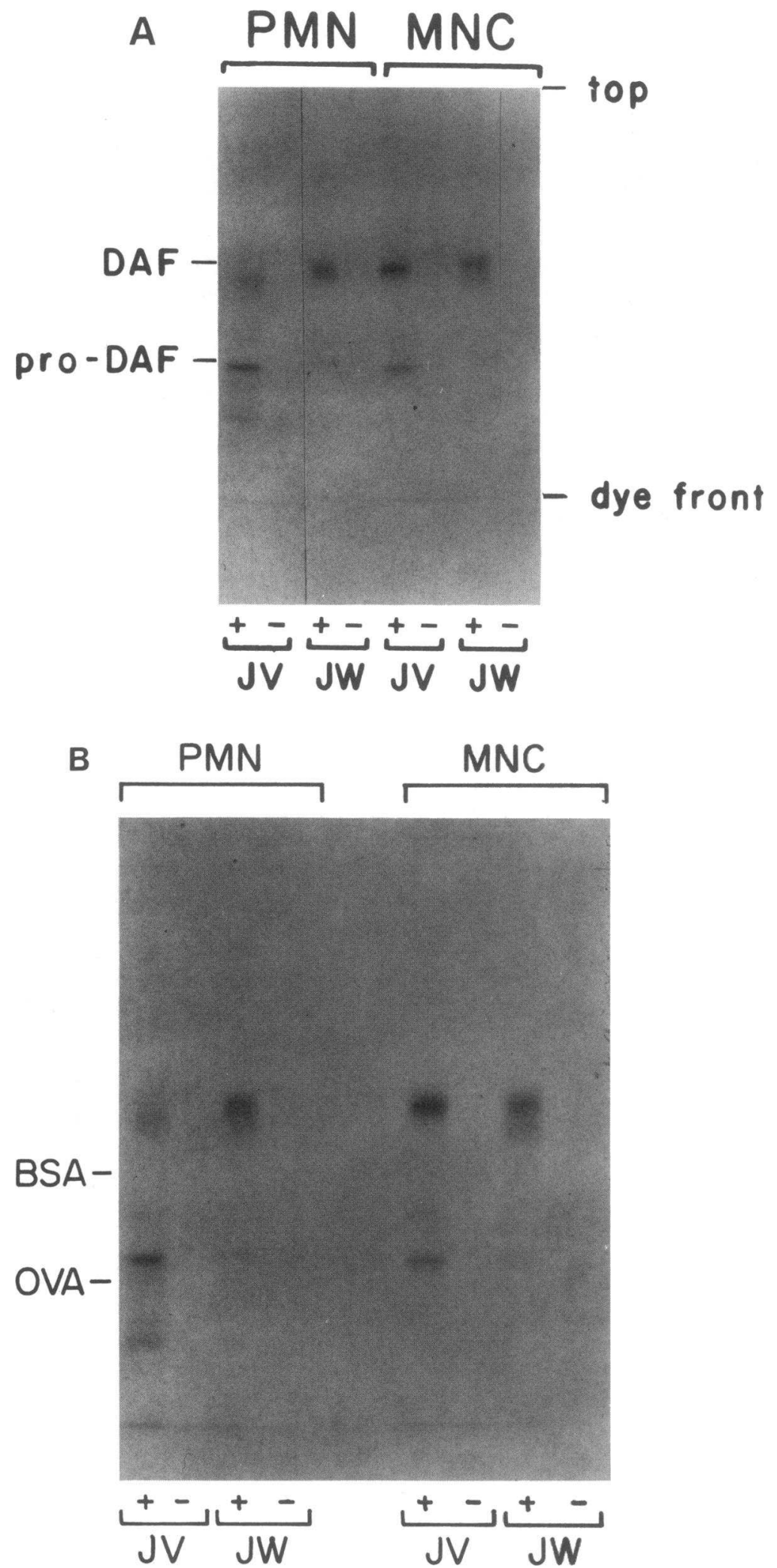

Figure 2. Biosynthetic labeling of PMN and MNC from a patient with PNH III E and a control individual. PMN or MNC were biosynthetically labeled with $\left[{ }^{35} S\right]$ Cys and after extraction of cells, newly synthesized DAF proteins were analyzed by SDS-PAGE/fluorography. + and designate specific and nonspecific immunoprecipitates. Studies of PNH patient J.V. (with type III E and > 98\% DAF-negative leukocytes) are compared with those of a normal control J.W. A, Standard 7.5\% PAGE/fluorograph for examination of products. The more abundant precursor and less abundant mature DAF molecules in J.V.'s cells appear smaller in size than those in J.W.'s cells. $B$, Long-run 7.5\% PAGE/fluorograph for estimation of molecular mass differences. The aberrant precursor and mature DAF proteins in J.V.'s cells exhibit apparent $M_{\mathrm{r}} \mathrm{s}$ of 44,000 and 77,000 , respectively. In $A$ the positions of the gel top and dye front are shown, and in $B$ size markers are indicated.

leukocytes lack hydrophobic domains, two types of experiments were performed.

In the first, extracts of $\left[{ }^{35} \mathrm{~S}\right]$ Cys-labeled PMN from PNH patient C.P. and control D.C. were mixed with Triton X-114, a detergent which, upon micellar aggregation and centrifugation, partitions into hydrophobic and hydrophilic phases (34). After separation, the two phases were immunoprecipitated with anti-DAF or nonrelevent MAbs, and labeled proteins in 


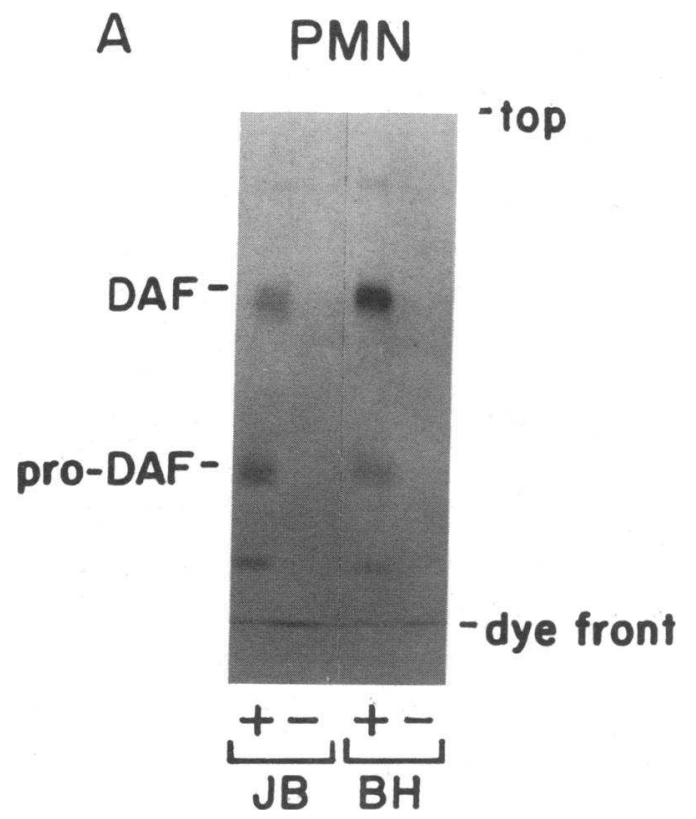

the immunoprecipitates were analyzed by SDS-PAGE/fluorography. As seen in Fig. 4, normal precursor as well as mature DAF molecules synthesized by the control cells partitioned virtually entirely into the detergent phase (lane 5) in accordance with previous findings (19) that GPL-anchor structures are incorporated into precursor DAF protein before Golgi processing. In contrast, the aberrant precursor and mature DAF peptides synthesized by the PNH cells partitioned predominantly into the aqueous phase (lane 3), indicating that they both lacked anchoring structures. As observed in studies of J.V. (see above), densimetric analysis showed that of $76 \%$ of

Table I. Soluble DAF Antigen in Cell Cultures* and Plasmas ${ }^{\ddagger}$

\begin{tabular}{|c|c|c|c|c|c|c|}
\hline & \multicolumn{2}{|c|}{ PMN } & \multicolumn{2}{|c|}{ MNC } & \multicolumn{2}{|c|}{ Plasma } \\
\hline & Mean & Mean \pm SD & Mean & Mean \pm SD & Mean & Mean \pm SD \\
\hline \multicolumn{7}{|c|}{ Normal controls } \\
\hline J.W. & 8 & & 5 & & 23 & \\
\hline K.M. & 2 & & 15 & & ND & \\
\hline \multirow[t]{2}{*}{ D.C. } & 10 & & 13 & & 27 & \\
\hline & & $6 \pm 4$ & & $11 \pm 5$ & & 25 \\
\hline \multicolumn{7}{|c|}{$\begin{array}{l}\text { PNH patients with } \\
\text { type III E }\end{array}$} \\
\hline \multirow[t]{2}{*}{ J.V. } & 37 & & 22 & & 68 & \\
\hline & & 37 & & 22 & & 68 \\
\hline \multicolumn{7}{|c|}{$\begin{array}{l}\text { PNH patients with } \\
\text { type II E }\end{array}$} \\
\hline J.B. & ND & & ND & & 138 & \\
\hline M.W. & 8 & & 7 & & 70 & \\
\hline C.P. & 19 & & 42 & & 32 & \\
\hline \multirow[t]{2}{*}{ D.O. } & ND & & ND & & 57 & \\
\hline & & 14 & & 24 & & $74 \pm 45$ \\
\hline
\end{tabular}

* ng DAF/5 ml culture media; ${ }^{\ddagger}$ ng DAF/ml after Ficoll-Hypaque. the total DAF protein in C.P.'s cells (lane 3), which partitioned into the aqueous phase, $23 \%$ was associated with the aberrant precursor as compared with only 5\% in D.C.'s cells (lane 5). In patient C.P., $24 \%$ of the total DAF protein corresponding to normal mature DAF molecules (presumably deriving from

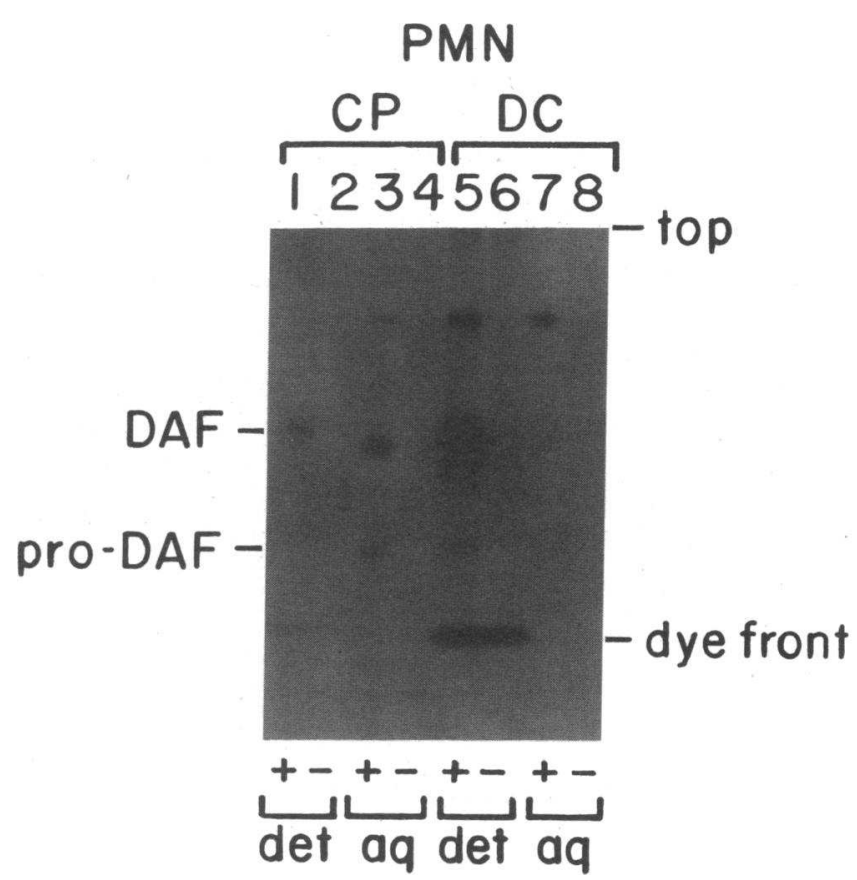

Figure 4. TX-114 detergent partitioning of DAF proteins synthesized by a patient with PNH II E. Biosynthetically labeled cell extracts from patient C.P. and control D.C. were partitioned into hydrophobic (detergent) and hydrophilic (aqueous) phases of Triton X-114. Anti-DAF (+) or nonrelevant (-) MAb immunoprecipitates were analyzed by SDS-PAGE/fluorography. Aberrant precursor and mature DAF protein in the PNH cells partitioned with the hydrophilic phase. 
unaffected DAF-positive PMN) partitioned into the hydrophobic phase (lane 1).

In the second set of experiments, PNH and normal PMN were labeled with $\left[{ }^{3} \mathrm{H}\right]$ ethanolamine, a precursor that incorporates into GPL-anchor structures (19). Uptake of the anchorprecursor into DAF proteins was then assessed by SDSPAGE/fluorography of anti-DAF immunoprecipitates (see Methods). To minimize interpretive complexities, patient J.V., with no detectable DAF-positive cells (Fig. 1), was studied. As shown in Fig. 5, whereas the $\left[{ }^{3} \mathrm{H}\right]$ ethanolamine incorporated normally into DAF protein in control cells, no labeling of DAF was observed in the PNH cells. Since ethanolamine is the most proximal GPL-anchor component, its absence implies the absence of more distal GPL-anchor constituents.

\section{Discussion}

The site of the cell lesion underlying defective expression of membrane molecules in PNH has not previously been identified. The experiments performed in this study demonstrate de novo biosynthesis of abnormal precursor and mature DAF proteins in affected PNH cells (Figs. 2 and 3). The proportion of precursor DAF protein in affected cells is greater than in normal cells. Although the proportion of mature DAF protein is markedly diminished, some is detectable. Both precursor and mature DAF molecules in affected PNH cells are smaller in apparent $M_{\mathrm{r}}$ than corresponding DAF species in normal cells. Moreover, soluble DAF protein is released into culture media of affected cells. In conjunction with previous observations (29) that DAF mRNA transcripts in affected PNH cells

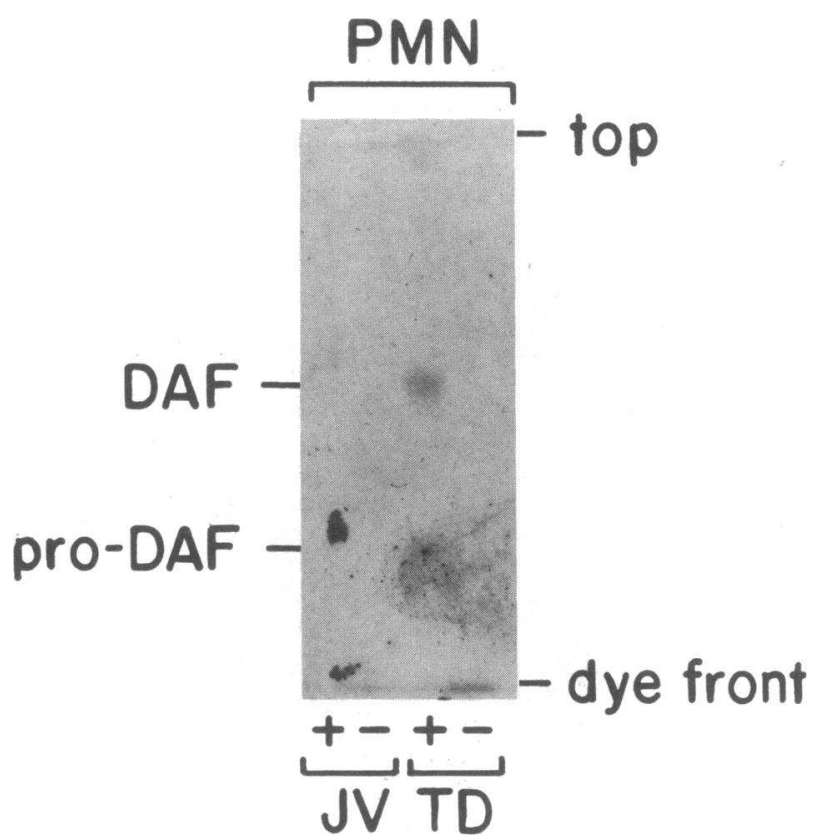

Figure 5. Ethanolamine labeling of PMN from a patient with PNH III $\mathrm{E}$ and a control individual. PMN were biosynthetically labeled with $\left[{ }^{3} \mathrm{H}\right]$ ethanolamine, and after extraction of cells newly synthesized DAF proteins were analyzed by SDS-PAGE/fluorography. + and - designate specific and nonspecific immunoprecipitates. Studies of PNH patient J.V. (type III E) are compared with those of control T.D. While DAF synthesized by control cells incorporates ethanolamine, DAF protein synthesized by PNH cells does not. are indistinguishable from those in normal cells, findings in this study (Figs. 4 and 5) that the PNH DAF proteins are hydrophilic and lack the proximal anchor constituent ethanolamine indicate that the defect in DAF synthesis in affected cells lies in abnormal COOH-terminal peptide/GPL-anchor substitution.

Studies of DAF biosynthesis in HeLa (19) and HL-60 (35) cells have shown that $\mathrm{N}$-glycosylation accounts for only $\sim 2,000$ of the apparent $M_{\mathrm{r}}$ of membrane DAF and that the marked $M_{\mathrm{r}}$ increase associated with conversion of pro-DAF into mature membrane DAF results from $O$-glycosylation in the Golgi. Consistent with these investigations, nucleotide sequence analyses of DAF cDNA $(27,28)$ have demonstrated that DAF contains only a single $N$-glycosylation site 61 residues from its $\mathrm{NH}_{2}$ terminus, and that it is unusually rich (in its membrane proximal region) in $\mathrm{Thr}$ and Ser $O$-glycosylation sites. Short-time pulse labeling experiments in HL-60 cells (35) have revealed a $43-\mathrm{kD}$ DAF precursor species that is rapidly converted into a 46-kD intermediate via a reaction independent of $\mathrm{N}$ - or $\mathrm{O}$-glycosylation. The biochemical modifications associated with this conversion have not been clarified, but our observation that abnormal precursor DAF protein in affected cells is $\sim 3,000$ smaller in apparent $M_{\mathrm{r}}$ than normal precursor DAF protein raises the possibility that the two species could represent intermediates in GPL-anchor processing.

Analyses of trypanosome variant surface glycoprotein biosynthesis performed with different labeled GPL-anchor precursors have shown parallel label incorporation kinetics indicating that GPL-anchors are added en bloc to nascent polypeptides of GPL-anchored proteins $(36,37)$. TLC analyses of extracts of Trypanosoma brucei simultaneously labeled with anchor components bearing different radionuclides have identified multiply labeled intracellular species, one of which, after PI-PLC digestion, exhibits migration changes characteristic of a phosphatidylinositol-containing structure $(38,39)$. These findings imply that GPL-anchors are preassembled in cells and are available for uptake upon encountering precursors of appropriate GPL-anchored acceptor polypeptides and predict that defective anchor assembly could abrogate anchor incorporation into GPL-anchored proteins. The findings in the present study that abnormal DAF precursors contained in PNH cells do not partition with the hydrophobic phase of Triton X-114 detergent and do not contain ethanolamine are in accordance with this prediction and further establish that truncated anchors are not incorporated. The $\sim 3 \mathrm{kD}$ smaller size and Triton X-114 aqueous phase partitioning of the abnormal peptides suggest that they lack the $\mathrm{COOH}$-terminal extension peptide predicted by DAF cDNA and thereby imply that $\mathrm{COOH}$-terminal signal peptidase activity is intact. This interpretation would be in accordance with recent findings that upon addition of rough microsomes to in vitro-synthesized nascent alkaline phosphatase polypeptides, $\mathrm{COOH}-$ terminal extension peptide excision occurred without GPL-anchor attachment (40). However, direct studies are necessary to formally establish this point in affected cells. Additionally, further studies will be required to determine if defective anchor incorporation into aberrant PNH DAF peptides is a consequence of an abnormality in anchor assembly or in its transfer to protein.

Complementation analyses of Thy-1-negative $\mathrm{T}$ lymphoma mutant cell lines (41) have demonstrated that failed expression of Thy-1 (a 25-kD murine brain- and lymphocyte- 
associated, GPL-anchored protein) can result from at least eight different defects, only two of which (classes D and G) involve altered transcription of the Thy- 1 gene. In the case of the other six defects, mutant cell lines (designated classes A-C, E, F, and H) synthesize Thy-1 antigen but fail to anchor the protein in the membrane, indicating that the defects in these cases involve abnormal GPL-anchoring. Different mutant cell lines exhibit differences in kinetics of Thy-1 degradation and secretion $(41,42)$. In class $E$ mutants, biosynthetic analyses have yielded conflicting data. In one study, secretion of aberrant Thy-1 peptide predominantly into culture media with some partitioning into Triton X-1 14 detergent was found (42), whereas in the other, retention of a Trp residue uniquely present in the Thy- $1 \mathrm{COOH}$-terminal extension peptide and predominant (PI-PLC resistant) partitioning into Triton X-114 detergent was observed (43). In class E cells, dolichol-phosphate mannose synthesis is abnormal (41) but the relationship of this abnormality to the defect in GPL-anchor uptake in this cell line is unknown.

The alterations of DAF proteins in affected PNH cells observed in the present study most closely resemble the abnormalities (with respect to Triton X-114 partitioning, ethanolamine labeling, and secretion) of Thy-1 proteins synthesized by class B mutant cells (41-43). The detection in the PNH cells of intact $O$-glycosylation as evidenced by the apparently normal increase in apparent $M_{\mathrm{r}}$ between the aberrant precursor and mature DAF forms is consistent with experimental observations for groups $\mathrm{A}-\mathrm{C}$ and $\mathrm{F}$ cells. The demonstration that multiple biochemical defects affecting GPL-anchor synthesis or attachment underlie Thy-1-negative lines suggests that more than one biosynthetic defect may similarly underlie the PNH phenotype.

\section{Acknowledgments}

The authors thank Dr. R. Weisman for providing patient M.W. samples, Dr. W. Rosse for performing complement lysis sensitivity assays, Dr. H. Stafford for providing some of the data in Fig. 1, Dr. S. Fatemi for helpful discussion, and Katherine Montgomery and Beth Finke for manuscript preparation.

This work was supported by National Institutes of Health grants AI-23598 and P01-DK-38181, and grants from the American Heart Association and American Cancer Society. Dr. Medof is an Established Investigator of the American Heart Association.

\section{References}

1. Medof, M. E. 1988. Decay-accelerating factor and the defect of paroxysmal nocturnal hemoglobinuria. In Cytolytic Lymphocytes and Complement Effectors of the Immune System. E. R. Podack, editor. CRC Press, Inc., Boca Raton, FL. 57-86.

2. Pangburn, M. K., R. D. Schreiber, J. S. Trombold, and H. J. Müller-Eberhard. 1983. Paroxysmal nocturnal hemoglobinuria. Deficiency in factor H-like functions of the abnormal erythrocytes. J. Exp. Med. 157:1971-1980.

3. Nicholson-Weller, A., J. P. March, S. I. Rosenfeld, and K. F. Austen. 1983. Affected erythrocytes of patients with paroxysmal nocturnal hemoglobinuria are deficient in the complement regulatory protein, decay-accelerating factor. Proc. Natl. Acad. Sci. USA. 80:5066-5070.

4. Pangburn, M. K., R. D. Schreiber, and H. J. Müller-Eberhard. 1983. Deficiency of an erythrocyte membrane protein with complement regulatory activity in paroxysmal nocturnal hemoglobinuria. Proc. Natl. Acad. Sci. USA. 80:5430-5434.
5. Medof, M. E., T. Kinoshita, and V. Nussenzweig. 1984. Inhibition of complement activation on the surface of cells after incorporation of decay-accelerating factor (DAF) into their membranes. J. Exp. Med. 160:1558-1578.

6. Auditore, J. V., R. C. Hartman, J. M. Flexner, and O. J. Balchum. 1960. The erythrocyte acetylcholinesterase enzyme in paroxysmal nocturnal hemoglobinuria. Arch. Pathol. 69:534-543.

7. Chow, F. L., S. E. Hall, W. F. Rosse, and M. J. Telen. 1986. Separation of the acetylcholinesterase-deficient red cells in paroxysmal nocturnal hemoglobinuria erythrocytes. Blood. 67:893-897.

8. Selvaraj, P., M. L. Dustin, R. Silber, M. G. Low, and T. A. Springer. 1987. Deficiency of lymphocyte function-associated antigen 3 (LFA-3) in paroxysmal nocturnal hemoglobinuria. J. Exp. Med. 166:1011-1025.

9. Dustin, M. L., P. Selvaraj, R. J. Mattaliano, and T. A. Springer. 1987. Anchoring mechanisms for LFA-3 cell adhesion glycoprotein at membrane surface. Nature (Lond.). 329:846-848.

10. Lewis, S. M., and J. V. Dacie. 1965. Neutrophil (leukocyte) alkaline phosphatase in paroxysmal nocturnal haemoglobinuria. $B r . J$. Haematol. 11:549-556.

11. Selvaraj, P., W. F. Rosse, R. Silber, and T. A. Springer. 1988. The major $\mathrm{Fc}$ receptor in blood has a phosphatidylinositol anchor and is deficient in paroxysmal nocturnal haemoglobinuria. Nature (Lond.). 333:565-567.

12. Low, M. G., and J. B. Finean. 1978. Specific release of plasma membrane enzymes by phosphatidylinositol-specific phospholipase $C$. Biochim. Biophys. Acta. 508:565-570.

13. Medof, M. E., A. Gottlieb, T. Kinoshita, S. Hall, R. Silber, V. Nussenzweig, and W. F. Rosse. 1987. Relationship between decay-accelerating factor deficiency, diminished acetylcholinesterase activity, and defective terminal complement pathway restriction in paroxysmal nocturnal hemoglobinuria erythrocytes. J. Clin. Invest. 80:165-174.

14. Medof, M. E., P. Selvaraj, M. L. Dustin, D. J. Ayers, E. I. Walter, H. A. Stafford, R. Green, M. L. Tykocinski, and T. A. Springer. 1987. Presence of LFA-3 in affected leukocytes of PNH patients with LFA-3 deficient erythrocytes. Complement. 4:192a. (Abstr.)

15. Kinoshita, T., M. E. Medof, R. Silber, and V. Nussenzweig. 1985. Distribution of decay-accelerating factor in the peripheral blood of normal individuals and patients with paroxysmal nocturnal hemoglobinuria. J. Exp. Med. 162:75-92.

16. Zalman, L. S., L. M. Wood, M. M. Frank, and H. J. MüllerEberhard. 1987. Deficiency of the homologous restriction factor in paroxysmal nocturnal hemoglobinuria. J. Exp. Med. 165:572-577.

17. Shin, M. L., G. M. Hänsch, V. Hu, and A. Nicholson-Weller. 1986. Membrane factors responsible for homologous restriction of complement-mediated lysis: evidence for a factor other than DAF operating at the stage of C8 and C9. J. Immunol. 136:1776-1782.

18. Haas, R., P. T. Brandt, J. Knight, and T. L. Rosenberry. 1986. Identification of amine components in the glycolipid membrane binding domain of the $\mathrm{C}$-terminus of human erythrocyte acetylcholinesterase. Biochemistry. 25:3098-3105.

19. Medof, M. E., E. I. Walter, W. L. Roberts, R. Haas, and T. L. Rosenberry. 1986. Decay-accelerating factor of complement is anchored to cells by a C-terminal glycolipid. Biochemistry. 25:67406747.

20. Low, M. G. 1987. Biochemistry of the glycosyl-phosphatidylinositol membrane protein anchors. Biochem. J. 244:1-13.

21. Low, M. G., and A. R. Saltiel. 1988. Structural and functional roles of glycosyl-phosphatidylinositol in membranes. Science (Wash. $D C)$. 239:268-275.

22. Zalman, L. S., L. M. Wood, and H. J. Müller-Eberhard. 1987. Inhibition of antibody-dependent lymphocyte cytotoxicity by homologous restriction factor incorporated into target cell membranes. J. Exp. Med. 166:947-955.

23. Hansch, G. M., P. F. Weller, W. White, and A. NicholsonWeller. 1988. C8 binding protein has a phosphatidylinositol membrane anchor. Clin. Res. 36:574a. (Abstr.) 
24. Sayama, K., H. J. Muller-Eberhard, and I. Gigli. 1988. Expression and modulation of homologous restriction factor (HRF) on peripheral white blood cells. Clin. Res. 36:619a. (Abstr.)

25. Cross, G. A. M. 1987. Eukaryotic protein modification and membrane attachment via phosphatidylinositol. Cell. 48:179-181.

26. Ferguson, M. A. J., and A. F. Williams. 1988. Cell surface anchoring of proteins via glycosyl-phosphatidylinositol structures. Annu. Rev. Biochem. 57:285-320.

27. Medof, M. E., D. M. Lublin, V. M. Holers, D. J. Ayers, R. R. Getty, J. F. Leykam, J. P. Atkinson, and M. L. Tykocinski. 1987. Cloning and characterization of cDNAs encoding the complete sequence of decay-accelerating factor of human complement. Proc. Natl. Acad. Sci. USA. 84:2007-2011.

28. Caras, I. W., M. A. Davitz, L. Rhee, G. Weddell, D. W. Martin, Jr., and V. Nussenzweig. 1987. Cloning of decay-accelerating factor suggests novel use of splicing to generate two proteins. Nature (Lond.). 325:545-549.

29. Stafford, H. A., M. L. Tykocinski, D. M. Lublin, V. M. Holers, W. F. Rosse, J. P. Atkinson, and M. E. Medof. 1988. Normal polymorphic variations and transcription of the decay-accelerating factor gene in paroxysmal nocturnal hemoglobinuria. Proc. Natl. Acad. Sci. USA. 85:880-884.

30. Shen, L., P. M. Guyre, and M. W. Fanger. 1987. Polymorphonuclear leukocyte function triggered through the high affinity $\mathrm{Fc}$ receptor for monomeric IgG. J. Immunol. 139:534-538.

31. Abramson, J. S., L. F. Cassidy, and D. S. Lyles. 1987. Synthesis of influenza A virus (IAV) and endogenous proteins in polymorphonuclear leukocytes (PMNLs). Pediatr. Res. 21:308a. (Abstr.)

32. Jack, R. M., and D. T. Fearon. 1988. Selective synthesis of mRNA and proteins by human peripheral blood neutrophils. J. Immunol. 140:4286-4293.

33. Laemmli, U. K. 1970. Cleavage of structural proteins during the assembly of the head of bacteriophage T4. Nature (Lond.). 227:680-685.
34. Bordier, C. 1981. Phase separation of integral membrane proteins in Triton X-114 solution. J. Biol. Chem. 256:1604-1607.

35. Lublin, D. M., J. Krsek-Staples, M. K. Pangburn, and J. P. Atkinson. 1986. Biosynthesis and glycosylation of the human complement regulatory protein decay-accelerating factor. J. Immunol. 137:1629-1635.

36. Ferguson, M. A. J., M. Duszenko, G. S. Lamont, P. Overath, and G. A. M. Cross. 1986. Biosynthesis of Trypanosoma brucei variant surface glycoproteins: $N$-glycosylation and addition of a phosphatidylinositol membrane anchor. J. Biol. Chem. 261:356-362.

37. Bangs, J. D., N. W. Andrews, G. W. Hart, and P. T. Englund. 1986. Posttranslational modification and intracellular transport of a trypanosome variant surface glycoprotein. J. Cell Biol. 103:255-263.

38. Krakow, J. L., D. Hereld, J. D. Bangs, G. W. Hart, and P. T. Englund. 1986. Identification of a glycolipid precursor of the Trypanosoma brucei variant surface glycoprotein. J. Biol. Chem. 261:12147-12153.

39. Menon, A. K., S. Mayor, M. A. J. Ferguson, M. Duszenko, and G. A. M. Cross. 1988. Candidate glycophospholipid precursor for the glycosyl-phosphatidylinositol membrane anchor of Trypanosoma brucei variant surface glycoproteins. J. Biol. Chem. 263:1970-1977.

40. Bailey, C. A., L. Gerber, A. D. Howard, and S. Udenfriend. 1989. Processing at the carboxyl terminus of nascent placental alkaline phosphatase in a cell-free system: evidence for specific cleavage of a signal peptide. Proc. Natl. Acad. Sci. USA. 86:22-26.

41. Hyman, R. 1988. Somatic genetic analysis of the expression of cell surface molecules. Trends Genet. 4:5-8.

42. Fatemi, S. H., and A. M. Tartakoff. 1988. The phenotype of five classes of T lymphoma mutants. J. Biol. Chem. 263:1288-1294.

43. Conzelmann, A., A. Spiazzi, R. Hyman, and C. Bron. 1986. Anchoring of membrane proteins via phosphatidylinositol is deficient in two classes of Thy-1 negative mutant lymphoma cells. EMBO (Eur. Mol. Biol. Organ.) J. 5:3291-3296. 